\title{
Analysis of Accuracy of Determination of Eccentric Point Coordinates of the KRAW Permanent Geodetic Station in RTK GPS Measuring Mode with the Application of the NAWGEO Service of the ASG-EUPOS System**
}

\section{Introduction}

Over four years since ASG EUPOS permanent geodetic stations started functioning in Poland, and it can be said that geodetic measurements conducted using GPS technology, and particularly in RTK GPS mode, decidedly increased their share in geodetic works and are still broadening their range. The sanctioning of the new Ordinance of the Minister of Internal Affairs and Administration of 9 November 2011 on technical standards of geodesic site and height measurements as well as for processing and transfer of the results of these measurements to the National Geodesic and Cartographic Resource was a very significant response to this state of affairs. This ordinance regulates many matters related to geodesic measurements and replaces many technical instructions used before it, but most importantly, it defines the modes and principles of conducting measurements using GPS technology. A great deal of the content relating to measurements using this technology has been taken directly from technical guidelines G-1.12.

One of the primary tasks of a geodesist conducting small, traditional site and height measurements is the creation of a geodetic control network. This is done most often by single or multiple measurement of a temporarily marked point (sign) using RTK GPS technology in picket measurement mode. At the same time, the new ordinance imposes the obligation of double measurement of every elements of the geodetic control point. Although it does not define the concept of double measurement of each element, based on the cited G-1.12 guidelines, it should be presumed that either measurement of such a point by double receiver initialization or by another measuring set, or measurement and development of observation in post-processing mode is being referred to here. In this case, if the accuracy of RTK GPS measurements

\footnotetext{
* AGH University of Science and Technology, Faculty of Mining Surveying and Environmental Engineering, Krakow, Poland

* This article was written within the framework of statutory studies 11.11.150.006
} 
is known, it can be acknowledged that the method of determination of a geodesic control network point referred to above (somewhat different than in the ordinance) is erroneous and unacceptable?

Another matter that arises frequently in discussions (e.g. internet forums) is the subject of the quality of GPS receivers used in geodesic measurements, their accura$\mathrm{cy}$, and reliability of positioning, function, and optimization of use of all parameters. Although price is still the most important factor during purchase, other attributes are becoming more and more important, such as intuitiveness, accuracy of coordinate determination, reliability, etc.

In this article, the primary goal was to compare the accuracy and reliability of obtained results of measurement in RTK GPS mode relative to values accepted as standard values using GPS receivers of various manufacturers. Processing of the results of this study also had the purpose of giving an answer to the question - does the method of making control networks in RTK GPS mode through single measurement of a point fulfill the accuracy criteria of the new ordinance. The presented goals were verified on the basis of the conducted research experiment.

\section{Research Experiment}

There is a KRAW permanent geodesic station of the ASG EUPOS system (Fig. 1) on the roof of the Faculty of Mining Survey and Environmental Engineering of AGH UST. This station also has two determined eccentric points, KRAW 8 and KRAW 9, located in Krakow. Their mutual situation is illustrated in Figure 2.

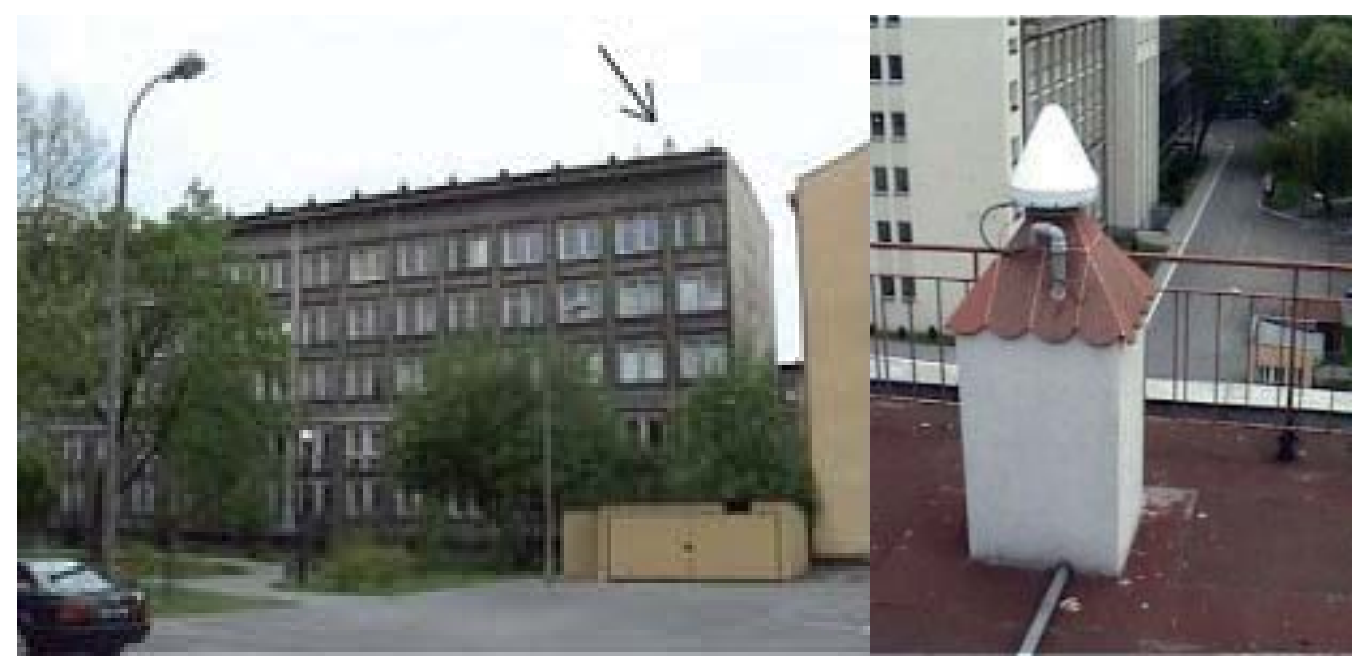

Fig. 1. Location of the KRAW permanent geodesic station of the ASG EUPOS system Source: www.asgeupos.pl. 


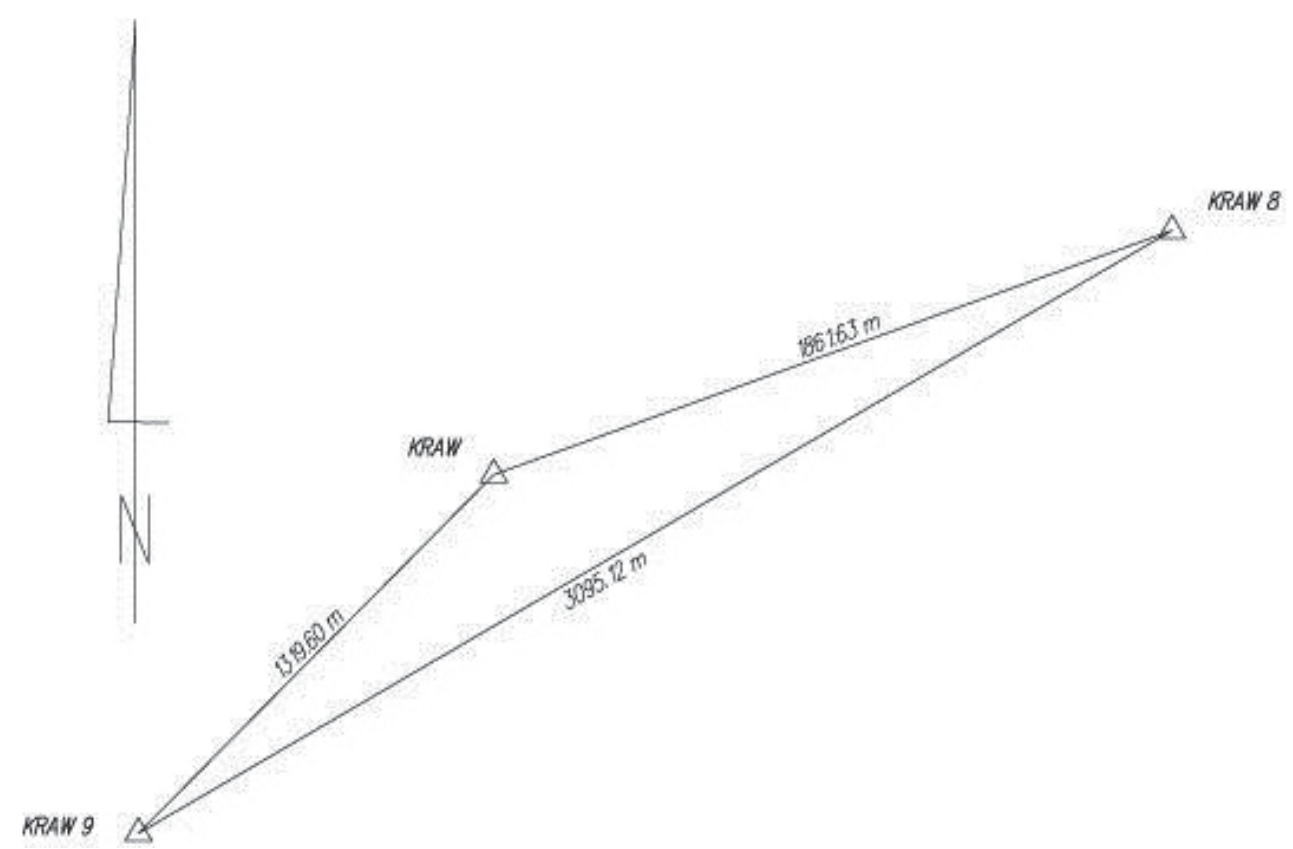

Fig. 2. Location of eccentric points KRAW 8 and KRAW 9 relative to the KRAW permanent geodetic station of the ASG EUPOS system

Two eccentrics of the KRAW station were selected for the experiments. The primary task was to measure points in RTK GPS mode using two GPS receivers from various manufacturers and to verify obtained results. The instruments used in studies were: a GPS receiver of the Topcon Hiper Pro company with an integrated antenna, and a receiver from the Trimble SPS851 company with a Zephyr Geodetic II antenna. Research points were measured with each of these receivers in RTK GPS mode with the application of surface corrections in RTCM 3.1 format in the NAWGEO service of the ASG EUPOS system. 65 measurements were conducted on each point with a five-second interval in terrain picket measurement mode. Measurements were cyclically repeated over one day. Four measuring cycles were conducted for each eccentric point, with breaks every three hours. All measurements were conducted under favorable weather conditions, with good constellation and satellite number (from 7 to 12), with PDOP value within the limits 1.4-2.8 and HRMS and VRMS errors $0.008-0.029 \mathrm{~m}$ and $0.010-0.033 \mathrm{~m}$ respectively. Measurements were conducted in the "2000" rectangular coordinate system, zone 7. Obtained results (coordinates) of eccentric point measurements in RTK GPS mode were related to the coordinates accepted as free from error, obtained during the ETRF 2000 measuring campaign. The course of coordinates $X, Y, H$ on eccentrics of the KRAW station is presented on Figures 3-8. Due to slight differences of coordinates in the four measuring cycles (Tab. 1), the presentation of results was simplified, with only the coordinate values from the first measuring cycle being shown on Figures 3-8. 
Table 1. Average values of the KRAW 8 and KRAW 9 eccentric coordinate points for each measuring cycle

\begin{tabular}{|c|c|c|c|c|c|c|c|}
\hline \multirow{2}{*}{ 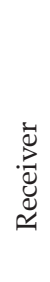 } & \multirow{2}{*}{ 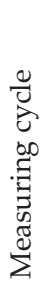 } & \multicolumn{3}{|c|}{ KRAW 8} & \multicolumn{3}{|c|}{ KRAW 9} \\
\hline & & $X[\mathrm{~m}]$ & $Y[\mathrm{~m}]$ & $H[\mathrm{~m}]$ & $X[\mathrm{~m}]$ & $Y[\mathrm{~m}]$ & $H[\mathrm{~m}]$ \\
\hline \multirow{4}{*}{ 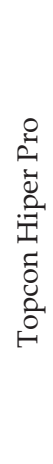 } & 1 & 5549064.578 & 7424428.275 & 255.513 & 5547321.007 & 7421870.992 & 245.147 \\
\hline & 2 & 5549064.569 & 7424428.272 & 255.501 & 5547321.015 & 7421870.991 & 245.150 \\
\hline & 3 & 5549064.579 & 7424428.275 & 255.512 & 5547321.016 & 7421870.995 & 245.149 \\
\hline & 4 & 5549064.578 & 7424428.278 & 255.513 & 5547321.012 & 7421870.990 & 245.145 \\
\hline \multirow{4}{*}{ 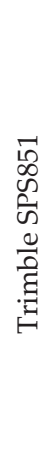 } & 1 & 5549064.572 & 7424428.280 & 255.504 & 5547321.007 & 7421870.998 & 245.149 \\
\hline & 2 & 5549064.576 & 7424428.272 & 255.507 & 5547321.005 & 7421870.996 & 245.156 \\
\hline & 3 & 5549064.569 & 7424428.279 & 255.507 & 5547321.006 & 7421870.992 & 245.159 \\
\hline & 4 & 5549064.571 & 7424428.279 & 255.501 & 5547321.009 & 7421870.996 & 245.143 \\
\hline
\end{tabular}

On Figures 3-8, besides the course of spatial coordinates of eccentric points of the KRAW station, their average value from multiple determination in picket measuring mode was illustrated, along with the value accepted as error-free. In turn, Figure 9 presents standard deviation for the determined $X, Y, H$ coordinates of the KRAW 8 and KRAW 9 eccentrics. 


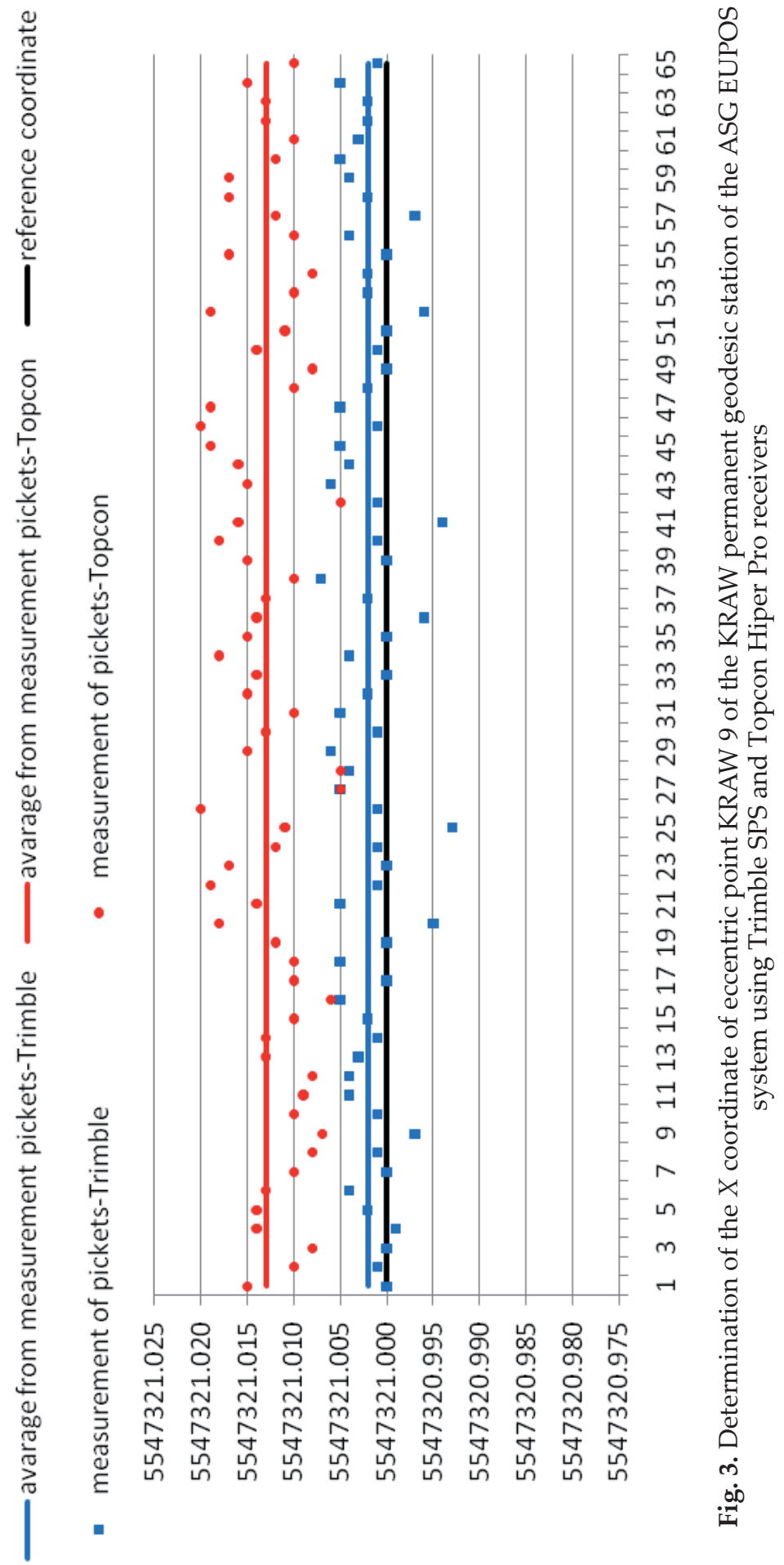




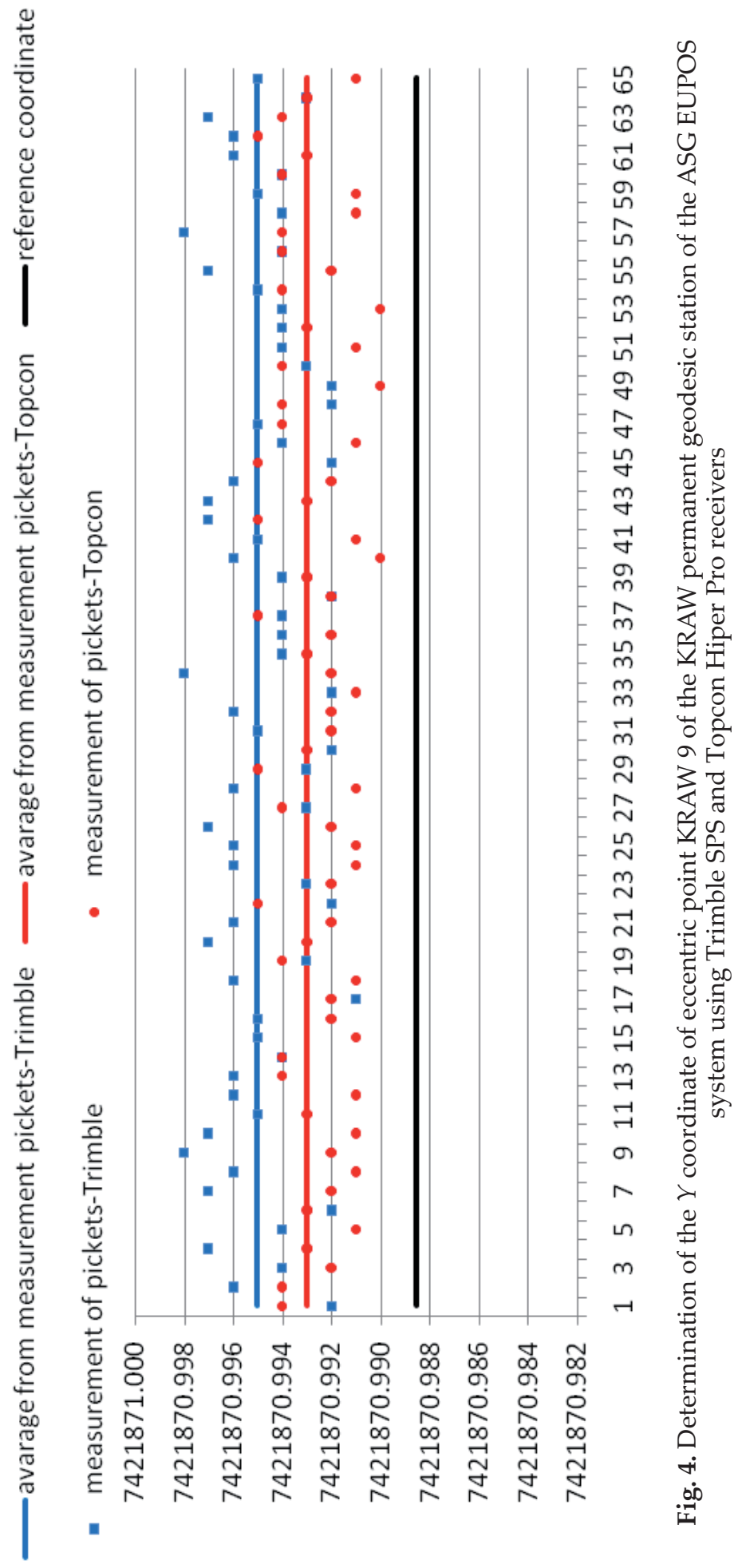




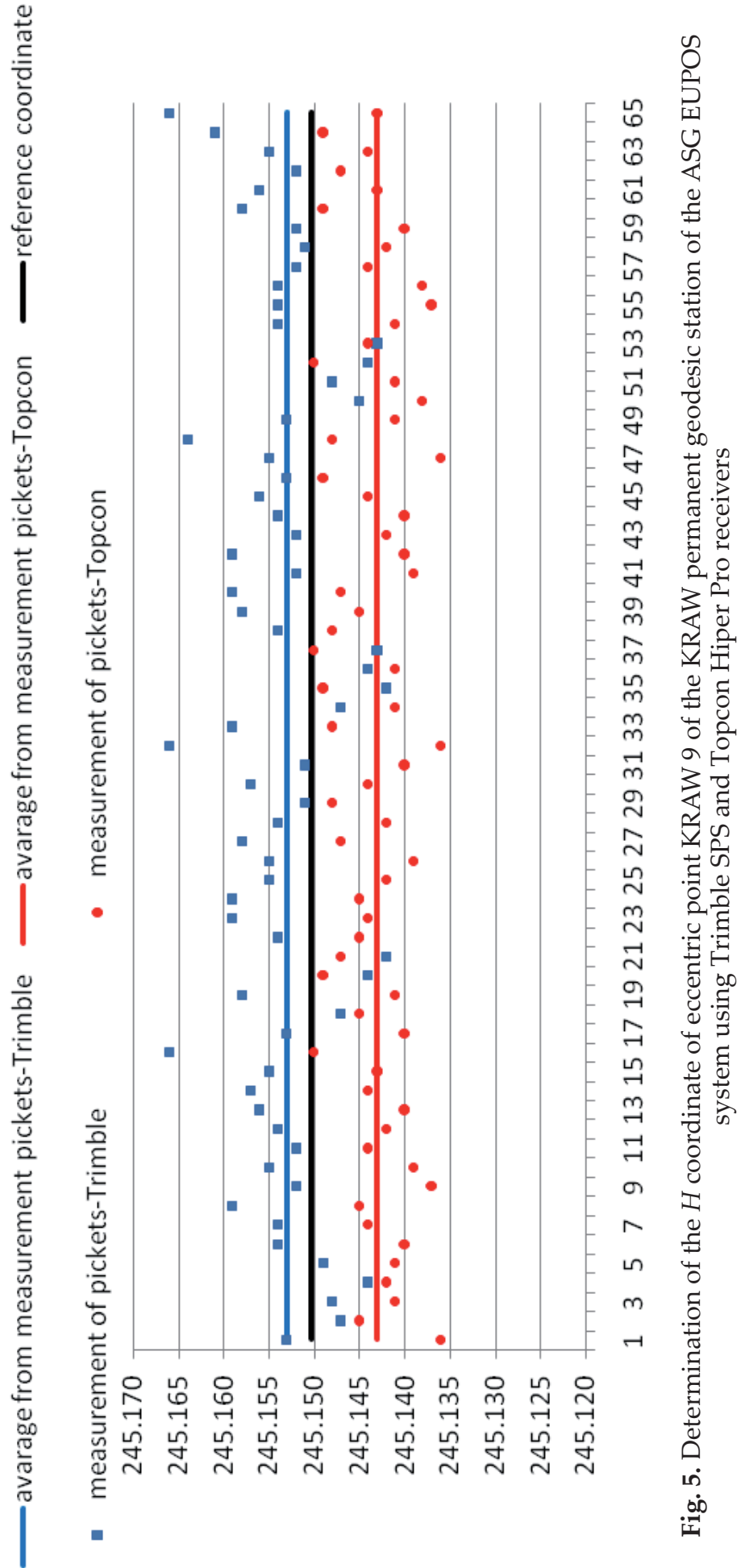




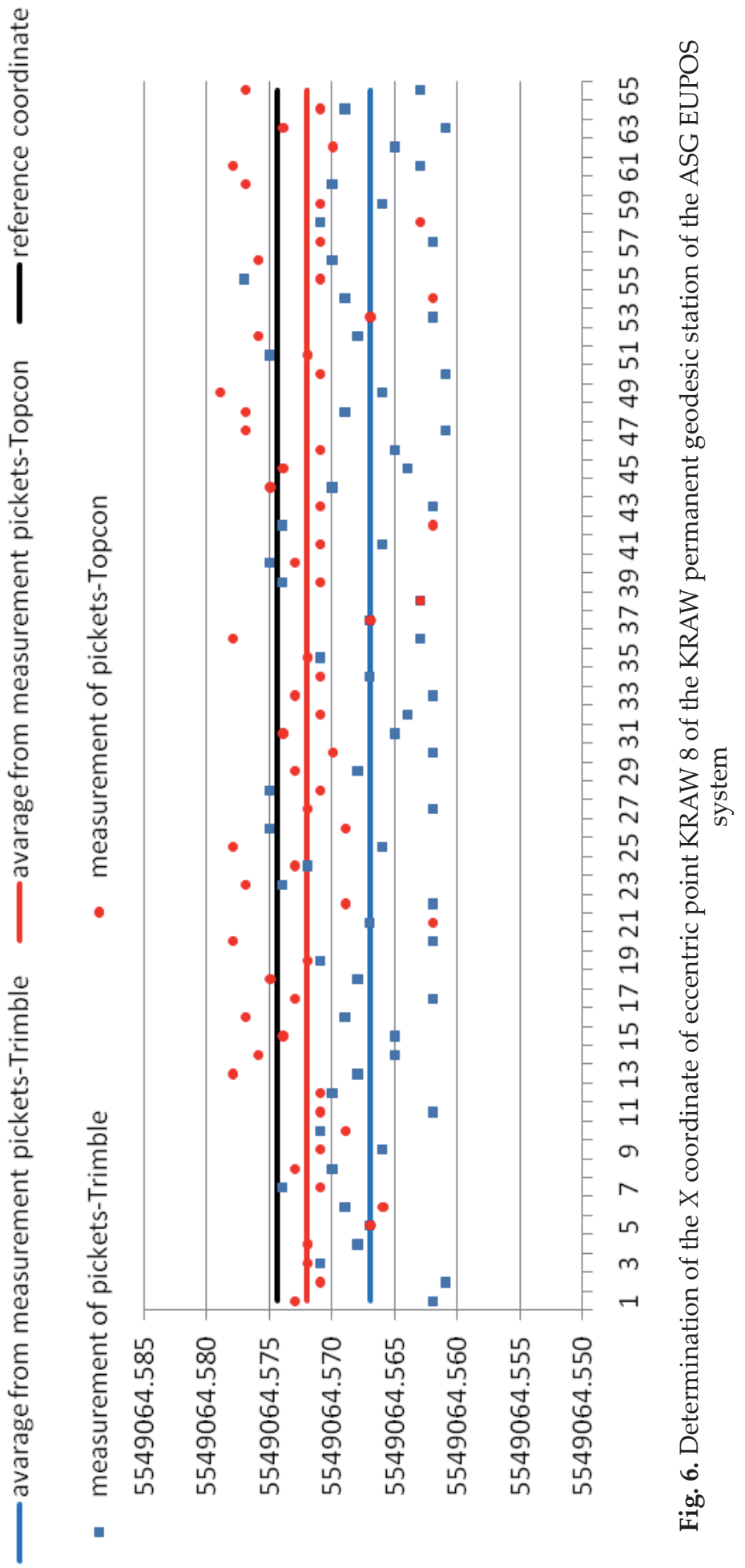




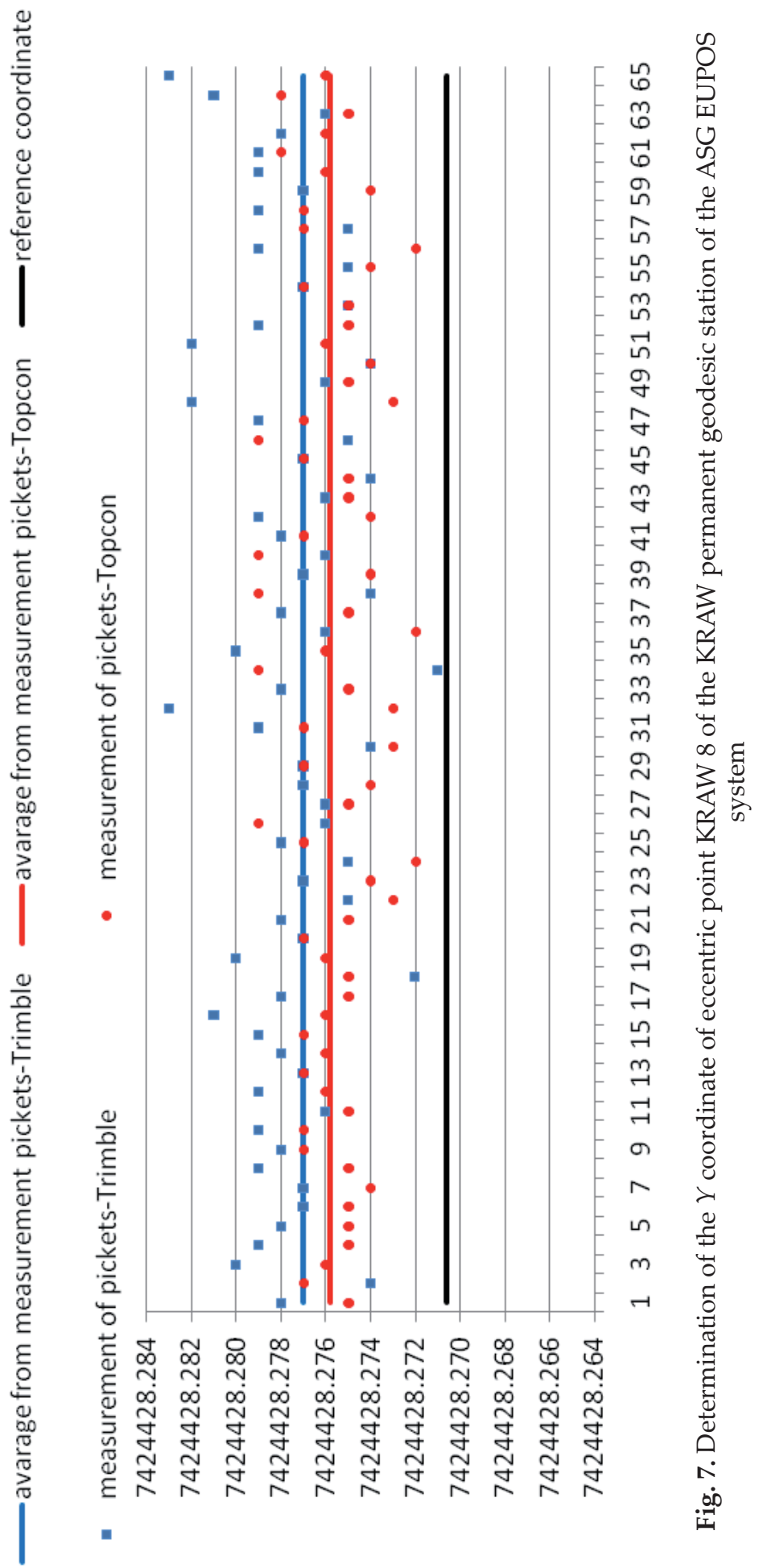




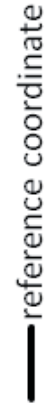

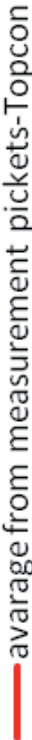

음

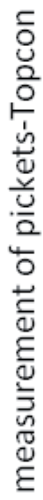

0
0
$0 \quad 5$

ปั

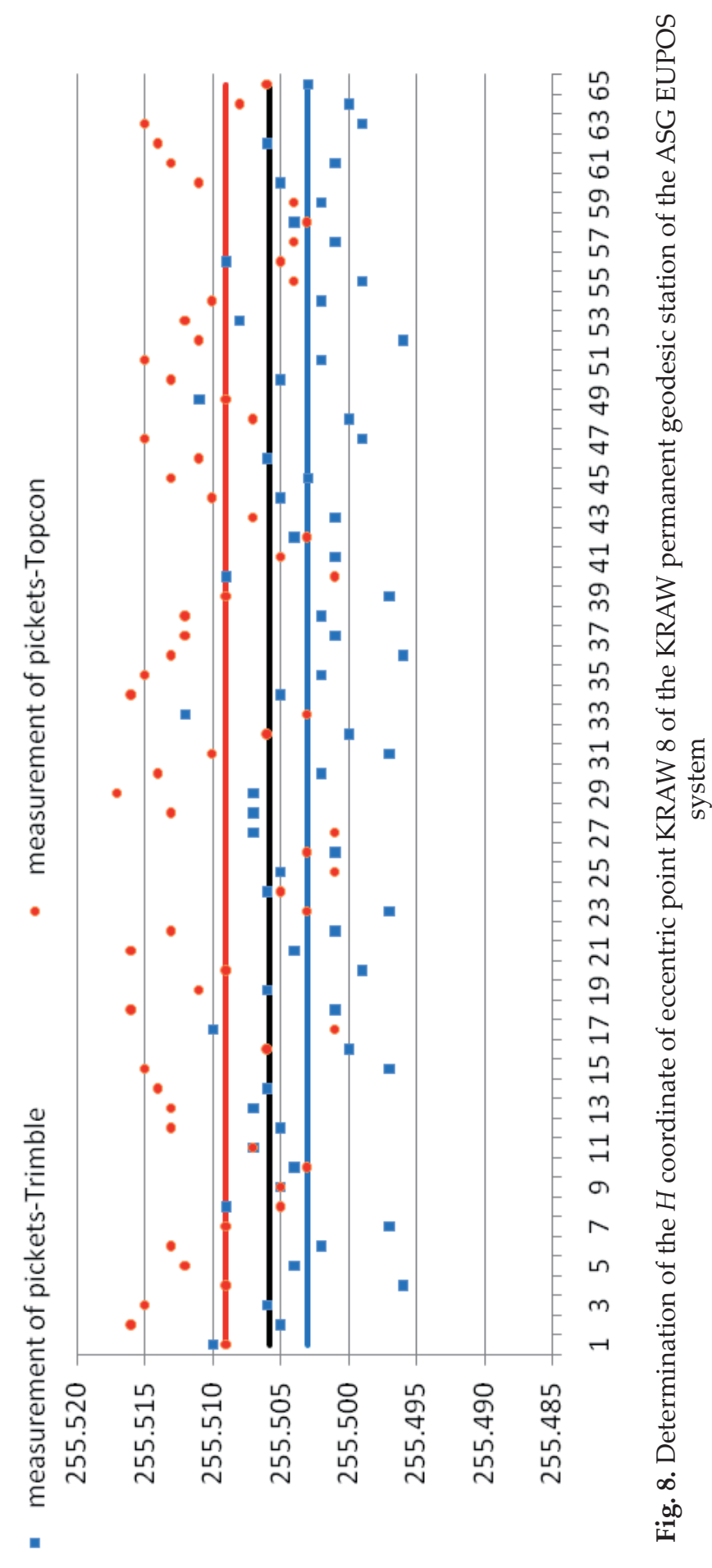




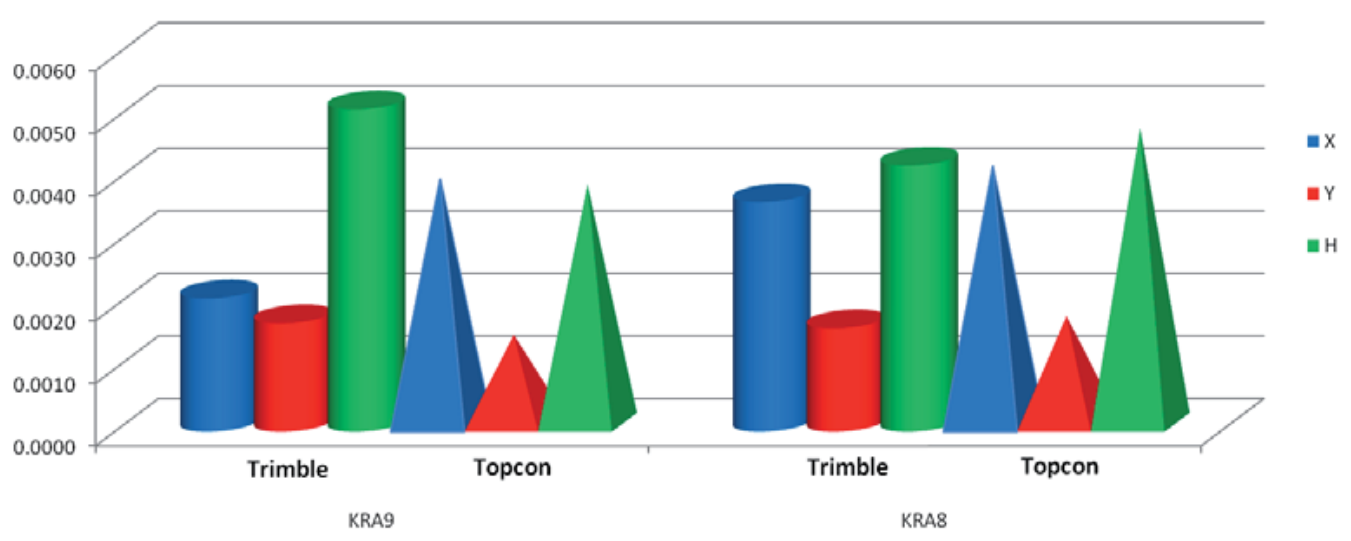

Fig. 9. Standard deviation for the $X, Y, H$ coordinates of eccentric points KRAW 8 and KRAW 9 of the KRAW permanent geodesic station of the ASG EUPOS system for Trimble and Topcon receivers

Based on analysis of the charts on Figures 3-9 and of the data in Table 1, conclusion can be made as to the accuracy and reliability of obtained results of measurements in RTK GPS mode, and these observations can be related to the methods of creating geodesic control networks referred to in the introduction. By comparing the results of spatial position of eccentric points over time, slight differences in the values of individual coordinates can be observed. A relation of their average values relative to one another or to error-free values also presents differences on the order of millimeters. These results are also not dependent on the type of receiver. In summary, it can be stated that the coordinate values of eccentric points obtained based on studies, as well as the coordinates of the same points obtained during the ETRF 2000 measuring campaign, are of the same order in terms of value.

\section{Conclusions.}

The generally known accuracy of point positioning in RTK GPS mode is at a level of $1-3 \mathrm{~cm}$ horizontally and up to $5 \mathrm{~cm}$ vertically. Based on this assumption and on expert opinions, certain principles concerning control point measurements and the method of creating a control network were accepted in the Ordinance of the Minister of Internal Affairs and Administration of 9 November 2011 on technical standards of geodesic site and height measurements as well as for processing and transfer of the results of these measurements to the National Geodesic and Cartographic Resource. The necessity of conducting RTK GPS measurements of at least two control points in the form of a geodesic control network and maintaining acceptable linear deviations is fully justified. However, the method of measurement during the creation of the control network in real-time is imprecisely defined, as mentioned in the introduction to the article. 
Based on this research experiment, it can be concluded that obtained results confirm the accuracy and reliability of obtaining measuring results in real-time. Furthermore, slight differences in obtained coordinates of research points at various time intervals and cycles suggest that a single measurement of a point in RTK GPS mode fulfills the accuracy criteria of the Ordinance [4].

\section{References}

[1] Wytyczne techniczne G-1.12: Pomiary satelitarne oparte na systemie precyzyjnego pozycjonowania ASG-EUPOS. Główny Geodeta Kraju, Warszawa 2008.

[2] Kudrys J., Krzyżek R.: Analysis of Coordinates Time Series Obtained Using the NAWGEO Service of the ASG-EUPOS System. Geomatics and Environmental Engineering, vol. 5, no. 4, 2011, pp. 39-46.

[3] Martin A., McGovern E.: An evaluation of the performance of network RTK GNSS services in Ireland. FIG Working Week 2012, Rome, Italy, 6-10 May 2012.

[4] Rozporzadzenie Ministra Spraw Wewnętrznych i Administracji z dnia 9 listopada $2011 r$. w sprawie standardów technicznych wykonywania geodezyjnych pomiarów sytuacyjnych i wysokościowych oraz opracowania i przekazywania wyników tych pomiarów do państwowego zasobu geodezyjnego i kartograficznego. Dz. U. z 2011 r. Nr 263, poz. 1572.

[5] ASG-EUPOS, [on-line:] http://www.asgeupos.pl/.

[6] Trimble® SPSx51 Modular GPS Receivers User Guide, Trimble, Version 3.70, Revision A. August 2008.

[7] Uradziński M., Doskocz A.: Initial analysis of the accuracy of position determination using ASG-EUPOS NAVGEO (RTK VRS) service. Geomatics and Environmental Engineering, vol. 4, no. 4, 2010, pp. 113-118. 